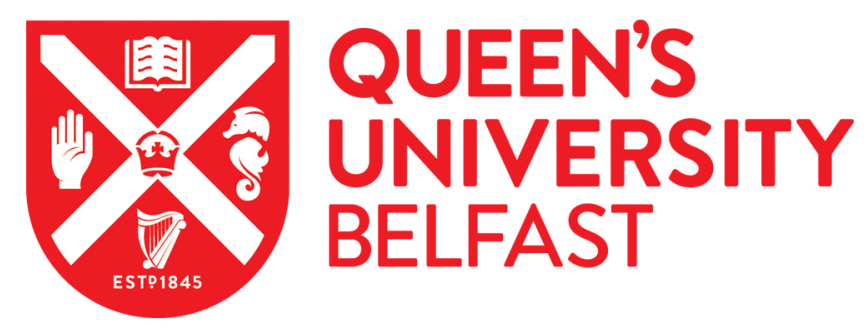

\title{
Pro-inflammatory mediator responses from neonatal airway epithelial cells and early childhood wheeze
}

Turner, S., Miller, D., Walsh, G., Scaifa, A., Power, U. F., Shields, M. D., \& Devereux, G. (2017). Pro-

inflammatory mediator responses from neonatal airway epithelial cells and early childhood wheeze. Pediatric Pulmonology, 53(1), 10-16. https://doi.org/10.1002/ppul.23915

Published in:

Pediatric Pulmonology

Document Version:

Peer reviewed version

Queen's University Belfast - Research Portal:

Link to publication record in Queen's University Belfast Research Portal

Publisher rights

Copyright 2017 Wiley. This work is made available online in accordance with the publisher's policies. Please refer to any applicable terms of use of the publisher.

\section{General rights}

Copyright for the publications made accessible via the Queen's University Belfast Research Portal is retained by the author(s) and / or other copyright owners and it is a condition of accessing these publications that users recognise and abide by the legal requirements associated with these rights.

Take down policy

The Research Portal is Queen's institutional repository that provides access to Queen's research output. Every effort has been made to ensure that content in the Research Portal does not infringe any person's rights, or applicable UK laws. If you discover content in the Research Portal that you believe breaches copyright or violates any law, please contact openaccess@qub.ac.uk. 


\section{PEDIATRIC PULMONOLOGY}

\section{Pro-inflammatory mediator responses from neonatal airway epithelial cells and early childhood wheeze}

\begin{tabular}{|c|c|}
\hline Journal: & Pediatric Pulmonology \\
\hline Manuscript ID & PPUL-17-0408.R4 \\
\hline Wiley - Manuscript type: & Original Article: Asthma \\
\hline Date Submitted by the Author: & $\mathrm{n} / \mathrm{a}$ \\
\hline Complete List of Authors: & $\begin{array}{l}\text { Turner, Steve; University of Aberdeen, Department of Child Health } \\
\text { Miller, David; University of Aberdeen, Child Health } \\
\text { Walsh, Garry; University of Aberdeen, Institute of Medical Science } \\
\text { Scaife, Alison; University of Aberdeen, Child Health } \\
\text { Power, Ultan; Queens' University Belfast, Centre of Infection and Immunity } \\
\text { Shields, Mike; Queens University Belfast, Child Health; } \\
\text { Devereux, Graham; University of Aberdeen, Environmental and } \\
\text { Occupational Medicine }\end{array}$ \\
\hline Keywords: & $\begin{array}{l}\text { Asthma \& Early Wheeze, Immunology and Immunodeficiency, Lung } \\
\text { Pathology, Epidemiology }\end{array}$ \\
\hline \multicolumn{2}{|l|}{ Other Keywords: } \\
\hline Abstract: & 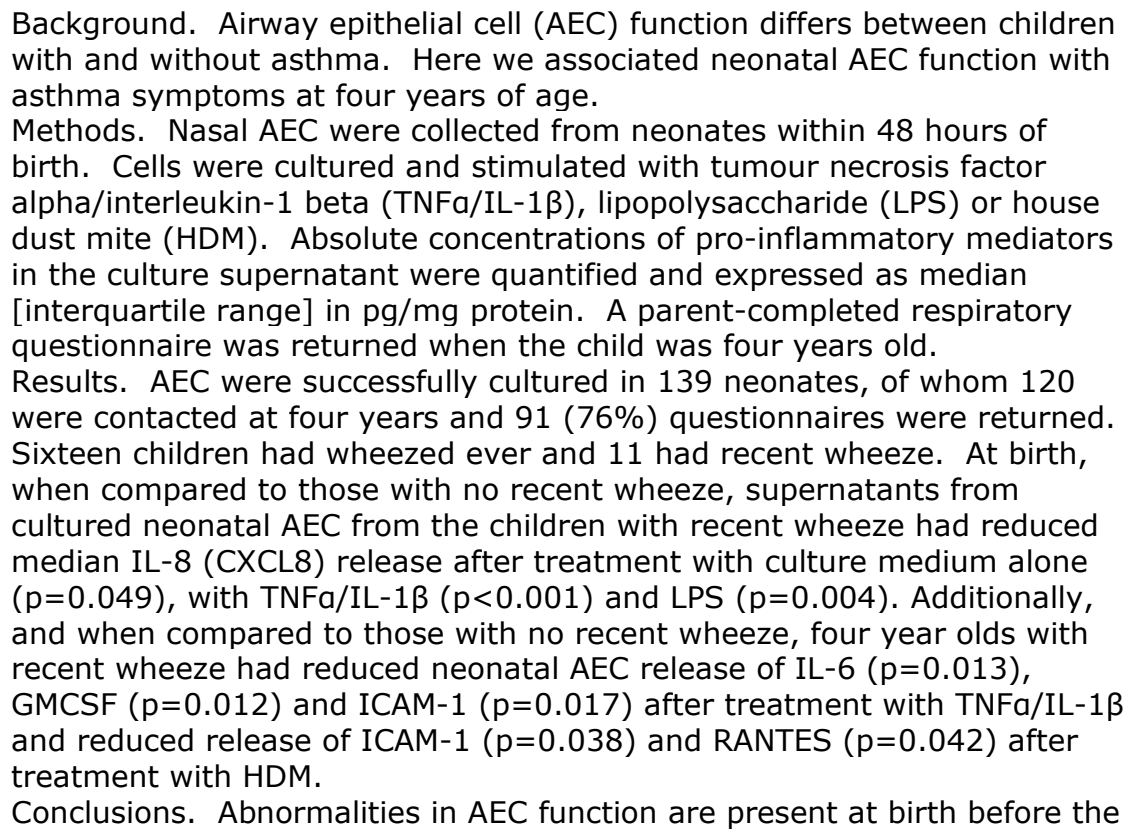 \\
\hline
\end{tabular}




\section{Page 1 of 32}

onset of childhood wheeze. The relationship between reduced AEC function at birth and wheeze at four years was not exclusive, suggesting that postnatal factors are required for the AEC abnormality to translate into symptoms.

John Wiley \& Sons, Inc. 
Pro-inflammatory mediator responses from neonatal airway epithelial cells and early childhood wheeze Steve Turner $\mathrm{MD}^{1}$, David Miller PhD ${ }^{1}$, Garry M. Walsh PhD², Alison Scaife ${ }^{2}$, Ultan F. Power PhD ${ }^{3}$, Michael D Shields $\mathrm{MD}^{3}$, Graham Devereux $\mathrm{PhD}^{1}$

${ }^{1}$ Child Health, University of Aberdeen, Aberdeen, UK, AB25 2ZG.

${ }^{2}$ Institute of Medical Sciences, University of Aberdeen, Aberdeen, UK, AB25 2ZD.

${ }^{3}$ Centre of Experimental Medicine, Queens' University Belfast, 97 Lisburn Road, Belfast, UK, BT9 7BL.

Running title: Neonatal airway cells and early wheeze

Contact details: $\operatorname{Dr}$ Steve Turner, Child Health, Royal Aberdeen Children's Hospital, Aberdeen, UK AB25 2ZG. Tel +44 1224 438570. s.w.turner@abdn.ac.uk

Key words. Asthma, Epithelial cell, Longitudinal Study, Neonate 


\begin{abstract}
Background. Airway epithelial cell (AEC) function differs between children with and without asthma. Here we associated neonatal AEC function with asthma symptoms at four years of age.

Methods. Nasal AEC were collected from neonates within 48 hours of birth. Cells were cultured and stimulated with tumour necrosis factor alpha/interleukin-1 beta (TNF $\alpha /$ IL-1 $\beta$ ), lipopolysaccharide (LPS) or house dust mite (HDM). Absolute concentrations of proinflammatory mediators in the culture supernatant were quantified and expressed as median [interquartile range] in $\mathrm{pg} / \mathrm{mg}$ protein. A parent-completed respiratory questionnaire was returned when the child was four years old.
\end{abstract}

Results. AEC were successfully cultured in 139 neonates, of whom 120 were contacted at four years and 91 (76\%) questionnaires were returned. Sixteen children had wheezed ever and 11 had recent wheeze. At birth, when compared to those with no recent wheeze, supernatants from cultured neonatal AEC from the children with recent wheeze had reduced median IL-8 (CXCL8) release after treatment with culture medium alone $(p=0.049)$, with TNF $\alpha /$ IL-1 $(p<0.001)$ and LPS $(p=0.004)$. Additionally, and when compared to those with no recent wheeze, four year olds with recent wheeze had reduced neonatal AEC release of IL-6 $(p=0.013)$, GMCSF $(p=0.012)$ and ICAM-1 $(p=0.017)$ after treatment with TNF $\alpha /$ IL-1 $\beta$ and reduced release of ICAM-1 $(p=0.038)$ and RANTES $(p=0.042)$ after treatment with HDM.

Conclusions. Abnormalities in AEC function are present at birth before the onset of childhood wheeze. The relationship between reduced AEC function at birth and wheeze at 
four years was not exclusive, suggesting that post-natal factors are required for the AEC abnormality to translate into symptoms.

\section{INTRODUCTION}

Asthma affects 5 million people in the UK, including 1.1 million children ${ }^{1}$. There is currently no cure for asthma and this is largely due to our lack of understanding of asthma aetiology. What is known is that genetic factors explain between $35 \%$ and $95 \%$ of asthma causation ${ }^{2}$ and that environmental factors are also important ${ }^{3}$. Asthma symptoms usually begin in childhood $^{4}$ and can persist into adult life ${ }^{5,6}$, and better understanding of the early origins of asthma may lead to novel interventions which palliate and cure symptoms.

Bias in the differentiation of the cellular immune system, where T-helper type 2 (Th2) lymphocytes predominated over Th1, was traditionally thought to be the critical process in the development of asthma ${ }^{7}$. More recently the primacy of the cellular immune system in the development of asthma has been questioned ${ }^{8}$ and airway epithelial cells (AEC) have been implicated in asthma causation ${ }^{9}$. The AEC provides a physical barrier against penetration of environmental exposures into the respiratory tissues, and this cell layer is now understood to be an important component of the innate immune system. Furthermore, AEC function is known to be different in children and adults with asthma compared to their non-asthmatic peers ${ }^{10-13}$. Although it is known that AEC abnormalities are present in asthma, the fundamental question as to whether this is present at birth, i.e. preceding the development of asthma and wheezing illness, remains unanswered.

We have collected nasal AEC within 48 hours of birth in a cohort ${ }^{14}$ and have followed up participants after four years. Nasal cells were sampled due to the difficult practical and ethical issues of sampling bronchial AEC in healthy neonates, and five studies described in a 
recent review ${ }^{10}$ have demonstrated similarities between nasal and bronchial AEC in a number of different settings. The aim of this study was to determine whether altered neonatal AEC pro-inflammatory responses constitute risk factors for later asthma symptoms. Wheeze in young children is often transient and does not progress to asthma, especially wheeze before the third birthday ${ }^{15}$. Here we test the hypothesis that AEC function was abnormal at birth in those who have asthma symptoms at four years of age. Since asthma is associated with atopic conditions such as eczema, we also stratified AEC function by asthma symptoms and eczema at four years of age. Our primary AEC outcome was interleukin (IL)-8 (CXCL8), and this was chosen because the secretion of this proinflammatory cytokine is enhanced by treatment with factors such as interleukin (IL)-1 $\beta$ and tumour necrosis factor alpha (TNF $\alpha$ ) or house dust mite (HDM) in both neonatal nasal AEC ${ }^{16}$ and bronchial AEC in children ${ }^{17}$.

\section{METHODS}

\section{Study subjects}

Recruitment took place at 10-12 weeks gestation, and details of parental asthma, smoking and socioeconomic status were collected. Within 48 hours of birth, nasal AEC were obtained by brushing and cultured in a submerged model ${ }^{16}$. In a subset of individuals there were sufficient cells available for cultured AEC to also be exposed to lipopolysaccharide (LPS). Close to the child's fourth birthday a postal questionnaire was completed. A third party $^{18}$ with permissions to access the child's contact details through Scottish healthcare records forwarded to parents of the study participants a questionnaire containing all the 
respiratory module questions of the International Study of Asthma and Allergy in Children (ISAAC) and also the question from the ISAAC eczema module for 6-7 year olds "has your child ever had eczema?" ${ }^{19}$. "Recent wheeze" was defined as wheeze in the last 12 months and was the primary outcome. "Never wheeze" was defined as negative responses to both "ever wheeze" and "wheeze in the last 12 months" questions. The recruitment phase of the study was approved by North of Scotland Research Ethics Service (reference number 10/S0802/55) and the follow up phase was approved by East Midlands- Nottingham 2 Research Ethics Committee (reference number 16/EM/0056). Written parental consent was obtained.

\section{Nasal brushing, AEC culture and stimulation}

The medial aspect of the inferior turbinate of each nostril was gently brushed using one sterile $2.7 \mathrm{~mm}$ interdental brush (Dento Care Professional, London UK) . Cells were placed into growth medium (Serum-free Bronchial Epithelial Growth Media, Lonza Ltd, Slough, UK) and cultured in submerged monolayers until confluence was reached. At 3-4 weeks after harvesting, tertiary passage $A E C$ were treated with : (i) $10 \mathrm{ng} / \mathrm{mL}$ Interleukin $1 \beta$ (IL-1 $\beta, R \& D$, Abingdon, UK) and $10 \mathrm{ng} / \mathrm{mL}$ Tumour Necrosis Factor- $\alpha$ (TNF- $\alpha, R \& D$, Abingdon, UK); (ii) 25 $\mu \mathrm{g} / \mathrm{mL}$ House Dust Mite (HDM, Greer Laboratories, Lenoir, NC, USA); (iii) $100 \mu \mathrm{g} / \mathrm{mL}$ Lipopolysaccharide (LPS, Sigma-Aldrich Ltd, Poole, UK); and (iv) medium alone. Growth medium was removed and replaced with $0.5 \mathrm{ml}$ of either fresh medium or the same volume of medium supplemented with experimental treatment as appropriate. After 24 hours of treatment, culture supernatants were removed and centrifuged at $500 \mathrm{rpm}$ for five minutes to remove cell debris before storing at $-20^{\circ} \mathrm{C}$ for subsequent analysis. The concentrations of the following cytokines and chemokines in the AEC medium were determined with 
cytometric bead array (Becton Dickinson, Oxford, UK): vascular endothelial growth factor (VEGF), regulated on activation normal T-cell expressed and secreted (RANTES/CCL5), monocyte chemoattractant protein (MCP)-1/CCL2, IL-3, IL-6, IL-10, IL-17A, interferon (IFN)- $\gamma$, granulocyte macrophage colony stimulating factor (GMCSF), eotaxin, macrophage inhibitory proteins (MIP) $1 \alpha / C C L 3$ and $1 \beta / C C L 4$, intracellular adhesion molecule (ICAM)-1 and tumour necrosis factor (TNF) $\alpha$. Interleukin-8/CXCL8 concentrations were determined by enzyme linked immunosorbent assay (Biolegend, San Diego, CA, USA). Once culture and exposure were complete and the overlay medium recovered, cells were lysed and the cellular protein content was determined by the Bradford Assay. Cytokine/chemokine concentrations $(\mathrm{pg} / \mathrm{mL})$ in the $0.5 \mathrm{~mL}$ overlay medium were normalised to $A E C$ protein content and expressed as the $\mathrm{pg} / \mathrm{mg}$ protein. The effect of exposure on absolute difference in AEC cytokine/chemokine release was calculated as the concentrations after treatment with IL$1 \beta / T N F \alpha$, LPS, HDM or growth medium alone

Analysis. The Mann Whitney test was used to describe the significance of differences in cytokines/chemokines between children with recent wheeze and without recent wheeze and also between those with recent wheeze and never wheeze. Where differences were seen between children with and without recent wheeze, cytokine/chemokine concentrations were compared across groups stratified by recent wheeze and eczema and significance determined using the Kruskal-Wallis test. Standard statistical software was used (IBM SPSS, version 23.0.0) and a p value of $<0.05$ was considered significant.

\section{RESULTS}

\section{Study subjects}


There were 269 mothers recruited, 192 neonates were sampled (many were taken home prior to sampling), and AEC cultured in 139 individuals of whom 120 were contacted and their questionnaires returned by 91 . Table one compares details of the 269 initially recruited and the 91 where a questionnaire was returned; the latter subgroup had a higher birth weight and lower prevalence of maternal eczema compared to the whole population. There were 11 children with recent wheeze, 16 had a history of wheeze ever and 32 had a history of eczema. No child had diagnosed asthma. Wheeze outcome was related to AEC IL8 release after exposure to growth media alone in 91 individuals, to IL-1 $\beta / T N F \alpha$ in 88 , to HDM in 72 and to LPS exposure in 38 (cells died during exposure or there were insufficient cells available for exposure in all cases). E-Table 1 demonstrates that those where results after treatment with IL-1 $\beta / T N F \alpha$, HDM and LPS were available were similar to the original population except for higher birth weight.

\section{Neonatal AEC cytokine/chemokine release and recent wheeze}

For AEC exposed only to growth medium, IL-8/CXCL8 release was lower in those with recent wheeze (median [IQR] $3530 \mathrm{pg} / \mathrm{mg}[1850,6310]$ ) compared to those with no recent wheeze (median 6829 [3850, 13948]), p=0.049), table 2, figure 1. Children with recent wheeze had reduced AEC release of IL-8/CXCL8 after stimulation with IL-1 $\beta$ and TNF $\alpha$ compared to those without recent wheeze ( $p<0.001$, figure 1). Additionally, AEC release of IL-6 (0.013), GMCSF $(p=0.012)$ and ICAM-1 $(p=0.017)$ was reduced after stimulation with IL-1 $\beta$ and TNF $\alpha$ in those with recent wheeze compared to no recent wheeze (table 2). The release of IL-8/CXCL8 was also reduced in children with recent wheeze after treatment with LPS $(p=0.004)$ compared to those with no recent wheeze (table 2). The AEC ICAM-1 ( $p=0.038$, table 2) and 
RANTES/CCL5 ( $p=0.042$, table 2 on line supplement) response to HDM were reduced among individuals with recent wheeze compared to those without recent wheeze.

We have previously reported associations between maternal dietary exposures during pregnancy and neonatal AEC release of TNF $\alpha, \mathrm{IL}-10$ and MIP-1 $\alpha / \mathrm{CCL}^{14}$, and there were reductions in TNF $\alpha$ levels after LPS exposure among 5 children with recent wheeze (median concentration $5 \mathrm{pg} / \mathrm{mg}[1,9])$ compared to 31 without (median $11[5,19]) \mathrm{p}=0.038$. There was no association between recent wheeze and neonatal AEC release of VEGF, MCP-1/CCL2, IL-17A, IFN- $\gamma$, eotaxin or MIP-1B/CCL4 under any treatment conditions (see E-Tables 2-5 in the online supplement). The differences in cytokine/chemokine responses between children with recent wheeze and a history of wheeze but not recent wheeze were also seen for the comparison between children with recent wheeze and never wheeze (online supplement E-Table 6).

\section{Neonatal AEC cytokine/chemokine release across groups stratified by recent wheeze and reported eczema}

There were 53 children with neither wheeze nor eczema, 26 with eczema no wheeze, 5 with wheeze no eczema and 6 with both wheeze and eczema. There was a difference $(p=0.003)$ across the groups for IL-8/CXCL8 release after exposure to IL-1 $\beta$ and TNF $\alpha$; median [IQR] values were as follows: no wheeze no eczema 108982 pg/mg protein [77893, 186455] n=52; eczema no wheeze 116590 [92410, 161968] n=26; wheeze no eczema 72085 [42748, 86760] $n=4$; wheeze and eczema 54955 [30680, 72003], n=6, figure 2. 


\section{DISCUSSION}

The present study was designed to relate in vitro nasal AEC release of pro-inflammatory mediators within 48 hours of birth to the presence of recent wheeze in these subjects at four years of age. The main finding was that AEC from neonates who had recent wheeze at the age of four years had reduced release of IL-8/CXCL8 by neonatal AEC stimulated with IL$1 \beta$ and TNF- $\alpha$ compared to children without recent wheeze. We also observed that when we stratified by eczema (a surrogate for atopy) there was no evidence that eczema modified the relationship between $A E C$ function and recent wheeze. Our results suggest that there is a congenital abnormality in AEC function which predisposes to childhood wheeze. However, there were many children in our cohort who did not progress to wheeze but had similarly low AEC cytokine/chemokine responses to those who did wheeze, and this suggests that higher AEC responses may confer protection against wheeze in early childhood and also that post-natal factors, including second hand smoke, inhaled chemicals, mould, ambient air pollutants and respiratory viruses ${ }^{3}$, may be required for lower AEC responses to translate into asthma symptoms. These results provide proof of concept but are based on a small number of individuals and require confirmation elsewhere.

There is a substantial literature, summarised in two recent reviews ${ }^{10,11}$, which demonstrates that in vitro AEC function is different in children with asthma compared to those without asthma but what has been uncertain is whether the AEC dysfunction is the cause or the consequence of asthma. Nasal AEC from newborn infants who subsequently developed wheeze released less IL-8/CXCL8, IL-6 and GMCSF compared to non-wheezing controls ${ }^{20}$ and bronchial AEC from adults with asthma have evidence of reduced innate immune responses 
after exposure to rhinovirus ${ }^{12,13}$. The findings of our study are consistent with these studies from children and adults and suggest that the differences precede the onset of symptoms.

There are some studies whose results are apparently inconsistent with our findings. For example, three studies have reported no difference in IL-8/CXCL8 release from bronchial AEC in children with and without asthma ${ }^{21-23}$, while others have reported increased release of pro-inflammatory mediators, such as $\mathrm{IL}-6^{21}$ and $\mathrm{VEGF}{ }^{24}$, in children with asthma compared to asymptomatic peers. One explanation for these apparent discrepancies between our study and others is that our AEC were assayed at a very early stage in the lifecourse compared to others, and secondary upregulation of AEC release of mediators, such as IL-6 and VEGF, may occur after the neonatal period as the nasal epithelium becomes colonised by microbial flora, infected with respiratory viruses and exposed to airborne pollutants.

There are a number of mechanisms which might explain why neonatal AEC cytokine/chemokine release was reduced in some individuals with recent wheeze at four years but this study was not designed to explore these mechanisms. The reductions in neonatal cytokine/chemokine release seen among some individuals with recent wheeze might plausibly be due to a reduced ability to recognise and/or respond to stimulation. There was a reduction in IL-8/CXCL8 release in untreated culture among those with recent wheeze compared to those without, and this suggests that there may be a constitutive defect in cytokine/chemokine responses in addition to an attenuated cytokine/chemokine response to stimulation. We have demonstrated that inclusion of children with wheeze ever but not in the last year among the no wheeze group did not affect the results and therefore 
the inconsistent relationship between low cytokine/chemokine response and wheeze at four years is not explained by some children in this group having transient wheeze.

There are some considerations which should be given to these results. First, the sample size was relatively small with only eleven children having had recent wheeze. However, the highly significant and large difference in IL-8/CXCL8 release (our cytokine/chemokine of primary interest) after exposure to IL-1 $\beta$ and TNF- $\alpha$ between children with and without wheeze is unlikely to be a false positive finding, as is the consistent reduction in AEC release of several cytokines/chemokines in association with later wheeze. The response of the respiratory system to early infection is widely considered to be important to the later development of asthma ${ }^{25}$ and the inflammatory mediators associated with later wheeze in this study are all recognised as being important to host airway response to infection: IL8/CXCL8 is a potent neutrophil chemo-attractant; IL-6 has both anti- and pro-inflammatory properties; $^{26}$ and ICAM-1 is a ligand for LFA1 (a receptor found on leukocytes ${ }^{27}$ ) and a receptor rhinovirus ${ }^{28}$. The analysis of AEC response after LPS exposure and where individuals were stratified by wheeze and eczema yielded very small groups with wheeze and these results should be treated with some caution. Alternatively the group with eczema but not wheeze was adequate in size to infer that there was no substantial difference compared to the group with neither eczema nor wheeze. Our study is limited by not collecting measurements of atopy or lung function. An additional limitation of our study was that the cohort recruited included $25 \%$ of mothers with a history of asthma and $5 \%$ who smoked, whereas the corresponding proportions in the general population are $10 \%$ and $20 \%$, so these results may not be generalisable. A final limitation is that we used a submerged model and an air-liquid interface model could have been more appropriate since it contains differentiated cells ${ }^{10}$. 
In summary, these findings suggest that a congenital abnormality in AEC responses to stimuli predispose children to developing wheeze later in life. The progress from wheeze in four year olds into diagnosed asthma in older children is not inevitable and we will follow up this group of children to determine whether the associations between neonatal AEC responses and wheeze persist. In the meantime, these novel findings now require confirmation in larger and older populations.

\section{ACKNOWLEDGEMENTS}

The authors would like to thank the study participants and their parents. The recruitment and sampling of this cohort was funded by the Chief Scientist Office, Edinburgh, UK (CAF/10/06). The follow up received no funding.

Competing interest statement. None of the authors has any competing interests. 


\section{REFERENCES}

1. Asthma UK. Asthma facts and Statistics. ; Available at:

https://www.asthma.org.uk/about/media/facts-and-statistics/. Accessed 03/07, 2016.

2. Ober C, Yao T. The genetics of asthma and allergic disease: a 21st century perspective. Immunol Rev 2011; 242(1): 10-30.

3. Dick S, Friend A, Dynes K, et al. A Systematic Review of Associations between

Environmental Exposures and Development of Asthma in Children Aged up to Nine Years. Brit Med J Open 2014; .

4. Grad R, Morgan WJ. Long-term outcomes of early-onset wheeze and asthma. Journal of Allergy \& Clinical Immunology 2012; 130(2): 299-307.

5. Tagiyeva N, Devereux G, Fielding S, Turner S, Douglas G. Outcomes of childhood asthma and wheezy bronchitis: a 50-year cohort study. Am J Respir Crit Care Med 2016; 193: 23-30.

6. Tai A, Tran H, Roberts M, Clark N, Wilson J, Robertson CF. The association between childhood asthma and adult chronic obstructive pulmonary disease. Thorax 2014; 9: 805.

7. Mosmann TR, Coffman RL. TH1 and TH2 cells: different patterns of lymphokine secretion lead to different functional properties. Annu Rev Immunol 1989; 7: 145-73.

8. Heaton T, Rowe J, Turner S, et al. An immunoepidemiological approach to asthma: identification of in-vitro T-cell response patterns associated with different wheezing phenotypes in children. Lancet 2005; 365(9454): 142-9. 
9. Holgate ST. The sentinel role of the airway epithelium in asthma pathogenesis. Immunol Rev 2011; 242(1): 205-19.

10. McClellan K, Shields M, Power U, Turner S. Primary airway epithelial cell culture and asthma in children-lessons learnt and yet to come. Pediatr Pulmonol 2015; DOI:

10.1002/ppul.23249.

11. Carsin A, Mazenq J, Ilstad A, Dubus JC, Chanez P, Gras d. Bronchial epithelium in children: a key player in asthma. Eur Respir Rev 2016; 25: 158-69.

12. Contoli M, Message SD, Laza-Stanca V, et al. Role of deficient type III interferonlambda production in asthma exacerbations. Nat Med 2006; 12(9): 1023-6.

13. Wark PAB, Johnston SL, Bucchieri F, et al. Asthmatic bronchial epithelial cells have a deficient innate immune response to infection with rhinovirus. J Exp Med 2005; 201(6): 93747.

14. Miller D, Turner SW, Spiteri-Cornish D, Scaife A, Danielan P, Devereux GS, Walsh GM. Maternal vitamin $\mathrm{D}$ and $\mathrm{E}$ intakes during early pregnancy are associated with airway epithelial cell responses in neonates. Clin Exp All 2015; DOI: 10.1111/cea.12490.

15. Henderson J, Granell R, Heron J, et al. Associations of wheezing phenotypes in the first 6 years of life with atopy, lung function and airway responsiveness in mid-childhood. Thorax 2008; 63(11): 974-80. 
16. Miller D, Turner SW, Spiteri-Cornish D, et al. Culture of airway epithelial cells from neonates sampled within 48-hours of birth. PLOS ONE [Electronic Resource] 2013; 8(11): e78321.

17. Mclnnes N, Davidson M, Scaife A, et al. Primary Paediatric Bronchial Airway Epithelial Cell in Vitro Responses to Environmental Exposures. Int J Environ Res Public Health 2016; 13: 359.

18. University of Aberdeen. Research Applications and Data Management. 2016; Available at: https://www.abdn.ac.uk/it/services/data-management/index.php. Accessed 08/15, 2016.

19. Asher MI, Keil U, Anderson HR, et al. International Study of Asthma and Allergies in Childhood (ISAAC): rationale and methods. European Respiratory Journal 1995; 8(3): 483-91.

20. McDougall CM, Helms PJ, Walsh GM. Airway epithelial cytokine responses in childhood wheeze are independent of atopic status. Respir Med 2015; 109(6): 689-700.

21. Kicic A, Sutanto EN, Stevens PT, Knight DA, Stick SM. Intrinsic biochemical and functional differences in bronchial epithelial cells of children with asthma. American Journal of Respiratory \& Critical Care Medicine 2006; 174(10): 1110-8.

22. Parker J, Sarlang S, Thavagnanam S, et al. A 3-D well-differentiated model of pediatric bronchial epithelium demonstrates unstimulated morphological differences between asthmatic and nonasthmatic cells. Pediatr Res 2010; 67(1): 17-22. 
23. Pringle EJ, Richardson HB, Miller D, Cornish DS, Devereux GS, Walsh GM, Turner SW. Nasal and bronchial airway epithelial cell mediator release in children. Pediatr Pulmonol 2012; 47(12): 1215-25.

24. Lopez-Guisa JM, Powers C, File D, Cochrane E, Jimenez N, Debley JS. Airway epithelial cells from asthmatic children differentially express proremodeling factors. Journal of Allergy \& Clinical Immunology 2012; 129(4): 990,7.e6.

25. Busse WW, Lemanske RFJ, Gern JE. Role of viral respiratory infections in asthma and asthma exacerbations. Lancet 2010; 376(9743): 826-34.

26. Hunter CA, Jones SA. IL-6 as a keystone cytokine in health and disease. Nat Immunol 2015; 16(5): 448-57.

27. Rothlein R, Dustin ML, Marlin SD, Springer TA. A human intercellular adhesion molecule (ICAM-1) distinct from LFA-1. J Immunol. 1986;137(4): 1270-4.

28. Greve JM, Davis G, Meyer AM, et al. The major human rhinovirus receptor is ICAM-1. Cell 1989; 56(5): 839-47. 


\section{FIGURE LEGENDS}

Figure one. Scatter plot comparing interleukin (IL) -8/CXCL8 release from neonatal nasal airway epithelial cells after 24 hours exposure to either medium alone or medium plus IL-1 $\beta$ and tumour necrosis factor (TNF)- $\alpha$ for individuals with parent-reported wheeze in the last 12 months at four years of age compared to no-wheeze controls. P values from Mann Whitney $U$ test. The horizontal lines indicate the mean IL-8/CXCL8 value.

Figure two. Scatter plot comparing interleukin (IL)-8/CXCL8 release from neonatal nasal airway epithelial cells after 24 hours exposure to either medium alone or to medium plus IL$1 \beta$ and tumour necrosis factor (TNF)- $\alpha$ for individuals stratified by parent-reported wheeze in the last 12 months and history of eczema at four years of age compared with nowheeze/no eczema controls. The $p$ value is from the Kruskal-Wallis test. There was no significant difference across the groups exposed to medium alone. The horizontal lines indicate the mean IL-8/CXCL8 value. 
1

2

3

4

5

6

7

8

9

10

11

12

13

14

15

16

17

18

19

20

21

22

23

24

25

26

27

28

29

30

31

32

33

34

35

36

37

38

39

40

41

42

43

44

45

46

47

48

49

50

51

52

53

54

55

56

57

58

59

60

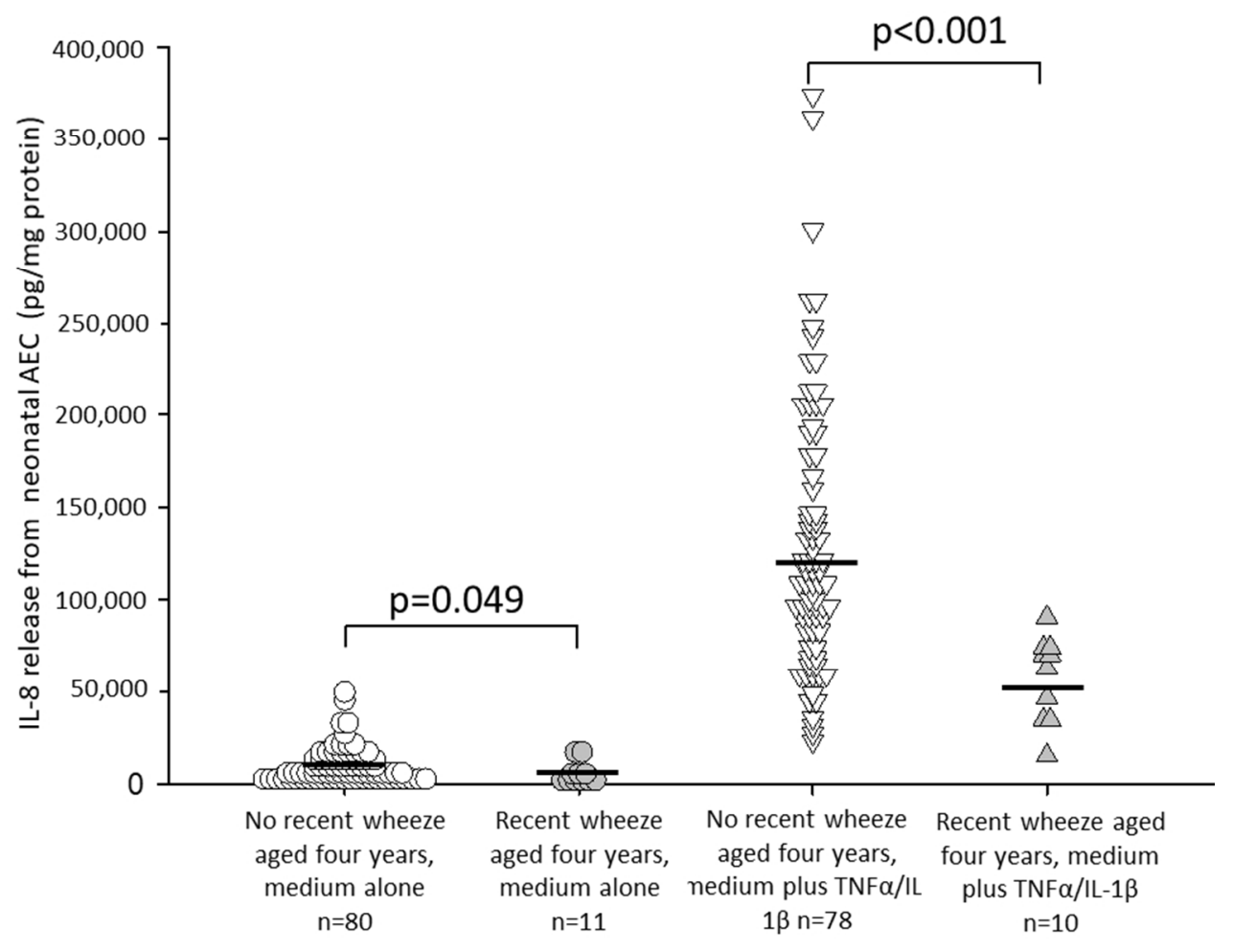

Figure one. Scatter plot comparing interleukin (IL) -8/CXCL8 release from neonatal nasal airway epithelial cells after 24 hours exposure to either medium alone or medium plus IL- $1 \beta$ and tumour necrosis factor (TNF)-a for individuals with parent-reported wheeze in the last 12 months at four years of age compared to no-wheeze controls. P values from Mann Whitney U test. The horizontal lines indicate the mean IL-8/CXCL8 value.

$254 \times 190 \mathrm{~mm}(96 \times 96 \mathrm{DPI})$

John Wiley \& Sons, Inc. 


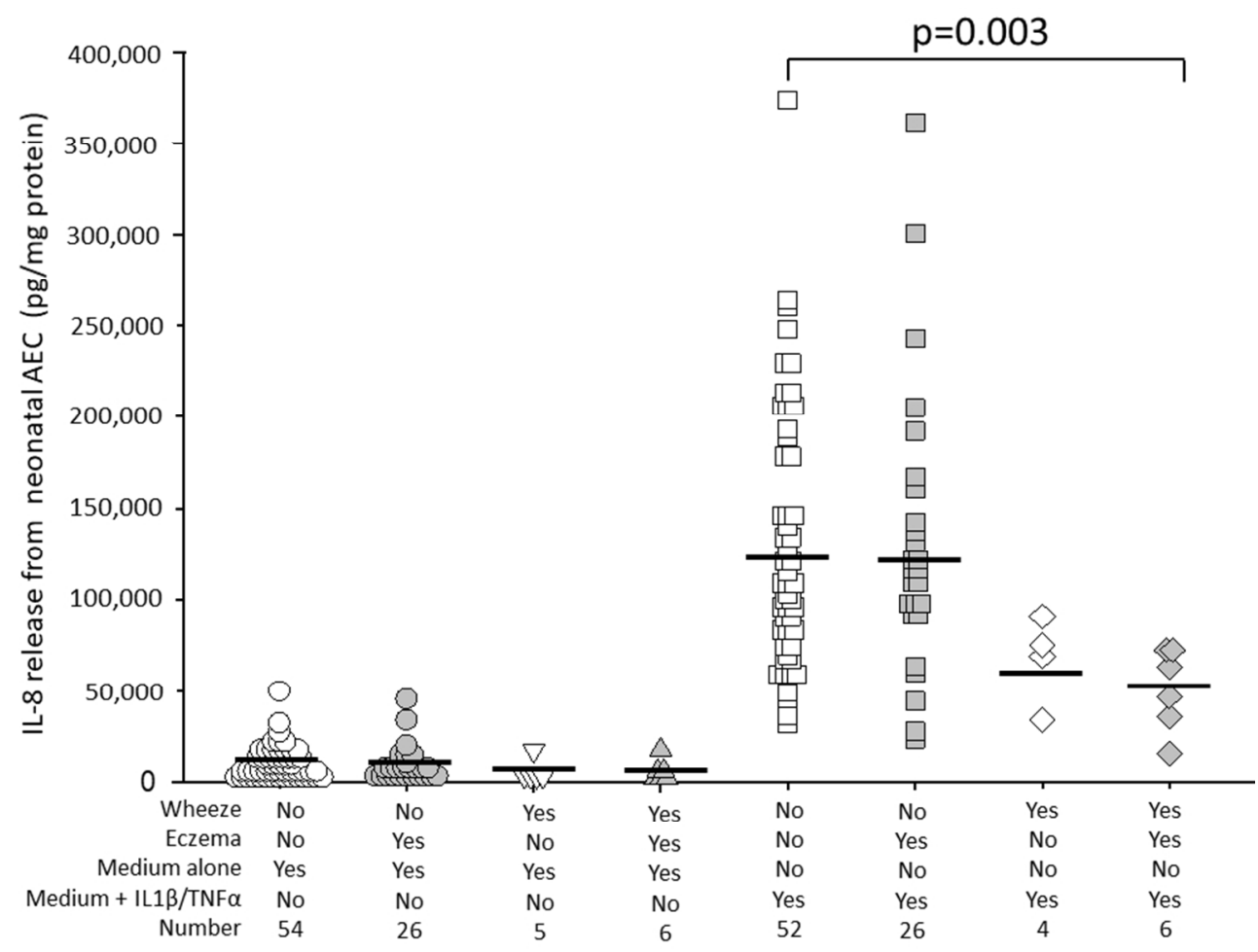

Figure two. Scatter plot comparing interleukin (IL)-8/CXCL8 release from neonatal nasal airway epithelial cells after 24 hours exposure to either medium alone or to medium plus IL-1 $\beta$ and tumour necrosis factor (TNF)- $a$ for individuals stratified by parent-reported wheeze in the last 12 months and history of eczema at four years of age compared with no-wheeze/no eczema controls. The $\mathrm{p}$ value is from the Kruskal-Wallis test. There was no significant difference across the groups exposed to medium alone. The horizontal lines indicate the mean IL-8/CXCL8 value.

$254 \times 190 \mathrm{~mm}(96 \times 96 \mathrm{DPI})$

John Wiley \& Sons, Inc. 
Table one. Comparison of maternal, paternal and neonatal characteristics for individuals in the original population recruited and those where questionnaire data were available at four years of age. SIMD=Scottish Index of Multiple Deprivations. IQR= interquartile range.

\begin{tabular}{|c|c|c|c|}
\hline & & $\begin{array}{c}\text { Recruited } \\
\text { (n=269 unless } \\
\text { stated) }\end{array}$ & $\begin{array}{l}\text { Questionnaire } \\
\text { data available } \\
\text { (n=91 unless } \\
\text { stated) }\end{array}$ \\
\hline \multirow{7}{*}{$\begin{array}{l}\text { Maternal } \\
\text { details }\end{array}$} & Mean maternal age (SD), years & $31.0(3.8)$ & $30.9(3.3)$ \\
\hline & Number of primagravida mothers (\%) & $158(59 \%)$ & $52(59 \%)$ \\
\hline & Number of mothers smoking (\%) & $14(5 \%)$ & $2(2 \%)$ \\
\hline & Median SIMD (IQR) & $\begin{array}{c}5283 \\
(4592,5993)\end{array}$ & $\begin{array}{c}5291 \\
(4769,5993)\end{array}$ \\
\hline & Number of mothers with a history of asthma (\%) & $67(25 \%)$ & $20(22 \%)$ \\
\hline & Number of mothers with a history of eczema (\%) & $48(18 \%)$ & $10(11 \%)^{*}$ \\
\hline & Number of mothers with a history of hayfever (\%) & $100(37 \%)$ & $30(33 \%)$ \\
\hline \multirow{3}{*}{$\begin{array}{l}\text { Paternal } \\
\text { details }\end{array}$} & Number of fathers with a history of asthma (\%) & $56(21 \%)$ & $16(18 \%)$ \\
\hline & Number of fathers with a history of eczema (\%) & $30(11 \%)$ & $9(10 \%)$ \\
\hline & Number of fathers with a history of hayfever (\%) & $77(29 \%)$ & $28(31 \%)$ \\
\hline \multirow[b]{4}{*}{ Neonatal } & Male Sex (\%) & $134(50 \%)$ & $46(51 \%)$ \\
\hline & Mean birth weight (SD), kg & $3.52(0.55)$ & $3.63(0.40)^{*}$ \\
\hline & Median age when nasal brushing taken (IQR), hrs & $\begin{array}{c}26(16,45) \\
n=192\end{array}$ & $25(16,40)$ \\
\hline & Median IL-8 concentration after exposure to IL-1 $\beta / T N F \alpha+(I Q R)$ & 107635 (69320, & $105685(69933$ \\
\hline
\end{tabular}




\begin{tabular}{|c|c|c|c|}
\hline details & & $\begin{array}{l}156720) \\
n=134\end{array}$ & $\begin{array}{c}157073) \\
n=88\end{array}$ \\
\hline & Median IL-6 concentration after exposure to IL-1 $\beta / T N F \alpha+($ IQR) & $\begin{array}{l}27670(9874, \\
56924) n=134\end{array}$ & $\begin{array}{c}28726(9813, \\
54007) \\
n=88\end{array}$ \\
\hline & $\begin{array}{l}\text { Median GMCSF concentration after exposure to IL-1 } \beta / \text { TNF } \alpha^{\dagger} \\
\text { (IQR) }\end{array}$ & $\begin{array}{l}693(267,1528) \\
n=134\end{array}$ & $\begin{array}{c}705(290,1549) \\
n=88\end{array}$ \\
\hline
\end{tabular}

cytokine/chemokine concentration is relative to cytokine/chemokine release after exposure to growth medium alone. 
Table 2. Median (interquartile range) cytokine concentration in the supernatant from neonatal nasal airway epithelial cell culture in groups stratified by the presence of recent wheeze at four years of age. The units are $p g / m g$ protein. ${ }^{*} p<0.001,+p=0.013, \neq p=0.012$, $\not p=0.017, \uparrow p=0.004, ¥ p=0.038$ and $\S p=0.049$.

\begin{tabular}{|c|c|c|c|}
\hline & Mediator & $\begin{array}{c}\text { Recent wheeze at four } \\
\text { years }\end{array}$ & No recent wheeze \\
\hline \multirow{4}{*}{$\begin{array}{l}\text { Median concentration } \\
\text { after treatment with IL- } \\
1 \beta \text { and TNF } \alpha \text { (IQR) }\end{array}$} & IL-8/CXCL8 & $\begin{array}{c}66080(35470,73988) \\
n=10^{*}\end{array}$ & $\begin{array}{c}112340(83493,177776) \\
n=78\end{array}$ \\
\hline & IL-6 & $7989(2262,27837) n=10^{+}$ & $30649(12643,54739) n=78$ \\
\hline & GMCSF & $130(64,852) n=10 \ddagger$ & $867(367,1562) n=78$ \\
\hline & ICAM-1 & $686(270,1253) n=10 x$ & $1288(680,2145) n=78$ \\
\hline \multirow{4}{*}{$\begin{array}{l}\text { Median concentration } \\
\text { after treatment with } \\
\text { lipopolysaccharide (IQR) }\end{array}$} & IL-8/CXCL8 & $3750(1720,12480) n=59$ & $17810(10260,38130) n=33$ \\
\hline & IL-6 & $2679(897,29650) n=5$ & $9983(741,40795) n=33$ \\
\hline & GMCSF & $31(12,55) n=5$ & $110(13,634) n=33$ \\
\hline & ICAM-1 & $30(12,55) n=5$ & $186(33,597) n=33$ \\
\hline \multirow{4}{*}{$\begin{array}{l}\text { Median concentration } \\
\text { after treatment with } \\
\text { house dust mite (IQR) }\end{array}$} & IL-8/CXCL8 & $5215(2615,22575) n=10$ & $19325(6568,35818) n=62$ \\
\hline & IL-6 & $622(55,17112) n=10$ & $15179(1931,25732) n=62$ \\
\hline & GMCSF & $5(0,460) n=10$ & $131(19,346) n=62$ \\
\hline & ICAM-1 & $48(0,255) n=10 ¥$ & $300(87,705) n=62$ \\
\hline \multirow{3}{*}{$\begin{array}{l}\text { Median concentration in } \\
\text { untreated culture (IQR) }\end{array}$} & IL-8/CXCL8 & $3530(1850,6310) n=11 \S$ & $6829(3850,13947) n=80$ \\
\hline & IL-6 & $1470(132,8244) n=11$ & $3884(901,10418) n=80$ \\
\hline & GMCSF & $12(2,212) n=11$ & $40(11,227) n=80$ \\
\hline
\end{tabular}


E-Table 1. Comparison of maternal, paternal and neonatal characteristics for individuals in the original population recruited and those where neonatal airway epithelial cells cytokine/chemokine responses were available. LPS=lipopolysaccharide. IL=interleukin. TNF=Tumour Necrosis Factor, HDM=House Dust Mite. SIMD=Scottish Index of Multiple Deprivations. IQR= interquartile range. ${ }^{*} p<0.05$ compared to all recruited.

\begin{tabular}{|c|c|c|c|c|c|}
\hline & $\begin{array}{c}\text { Recruited } \\
\text { (n=269 } \\
\text { unless } \\
\text { stated) }\end{array}$ & $\begin{array}{l}\text { Untreated } \\
\text { culture (n=91 } \\
\text { unless stated) }\end{array}$ & 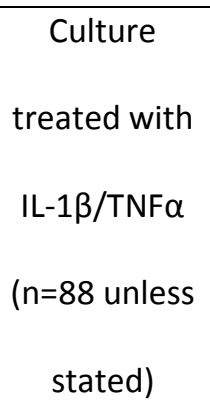 & $\begin{array}{c}\text { Culture } \\
\text { treated with } \\
\text { HDM ( } n=72 \\
\text { unless } \\
\text { stated) }\end{array}$ & $\begin{array}{l}\text { Culture } \\
\text { treated with } \\
\text { LPS ( } n=38 \\
\text { unless stated) }\end{array}$ \\
\hline Mean maternal age (SD), years & $31.0(3.8)$ & $30.9(3.3)$ & $30.8(3.3)$ & $30.7(3.2)$ & $31.2(3.3)$ \\
\hline Number of primagravida mothers (\%) & $158(59 \%)$ & $52(59 \%)$ & $52(59 \%)$ & $43(60 \%)$ & $24(63 \%)$ \\
\hline Number of mothers smoking every day (\%) & $14(5 \%)$ & $2(2 \%)$ & $2(2 \%)$ & $2(3 \%)$ & 0 \\
\hline Median SIMD (IQR) & $\begin{array}{c}5283 \\
(4592,5993)\end{array}$ & $\begin{array}{c}5291 \\
(4769,5993)\end{array}$ & $\begin{array}{c}5291 \\
(4769,5965)\end{array}$ & $\begin{array}{c}5290 \\
(4775,5930)\end{array}$ & $\begin{array}{c}5470 \\
(5134,6048)\end{array}$ \\
\hline $\begin{array}{r}\text { Number of mothers with a history of } \\
\text { asthma (\%) }\end{array}$ & $67(25 \%)$ & $20(22 \%)$ & $20(23 \%)$ & $14(19 \%)$ & $7(18 \%)$ \\
\hline $\begin{array}{r}\text { Number of mothers with a history of } \\
\text { eczema (\%) }\end{array}$ & $48(18 \%)$ & $10(11 \%)^{*}$ & $10(11 \%)$ & $9(13 \%)$ & $5(13 \%)$ \\
\hline $\begin{array}{r}\text { Number of mothers with a history of } \\
\text { hayfever (\%) }\end{array}$ & $100(37 \%)$ & $30(33 \%)$ & $29(33 \%)$ & $21(29 \%)$ & $14(37 \%)$ \\
\hline $\begin{array}{l}\text { Number of fathers with a history of asthma } \\
\text { (\%) }\end{array}$ & $56(21 \%)$ & $16(18 \%)$ & $16(18 \%)$ & $15(21 \%)$ & $8(21 \%)$ \\
\hline $\begin{array}{l}\text { Number of fathers with a history of eczema } \\
\text { (\%) }\end{array}$ & $30(11 \%)$ & $9(10 \%)$ & $9(10 \%)$ & $7(10 \%)$ & $5(13 \%)$ \\
\hline Number of fathers with a history of & $77(29 \%)$ & $28(31 \%)$ & $28(32 \%)$ & $21(29 \%)$ & $12(32 \%)$ \\
\hline
\end{tabular}

John Wiley \& Sons, Inc. 


\begin{tabular}{|c|c|c|c|c|c|}
\hline hayfever (\%) & & & & & \\
\hline Male Sex (\%) & $134(50 \%)$ & $46(51 \%)$ & $44(50 \%)$ & $37(51 \%)$ & $17(45 \%)$ \\
\hline Mean birth weight (SD), kg & $3.52(0.55)$ & $3.63(0.43)^{*}$ & $3.62(0.43)^{*}$ & $3.62(0.43)^{*}$ & $3.62(0.41)$ \\
\hline $\begin{array}{r}\text { Median age when nasal brushing taken } \\
\text { (IQR), hrs }\end{array}$ & $\begin{array}{c}26(16,45) \\
n=192\end{array}$ & $25(16,40)$ & $25(16,40)$ & $28(19,40)$ & $29(17,42)$ \\
\hline $\begin{array}{l}\text { Median increase in IL-8 concentration after } \\
\text { exposure to IL-1 } \beta / T N F \alpha+(\text { IQR) }\end{array}$ & $\begin{array}{c}95945 \\
(61210 \\
143640) \\
n=134\end{array}$ & - & $\begin{array}{r}95680 \\
(61925 \\
142645)\end{array}$ & $\begin{array}{r}93100 \\
(60190 \\
140500)\end{array}$ & $\begin{array}{r}94310 \\
(62675 \\
162712)\end{array}$ \\
\hline $\begin{array}{l}\text { Median increase in IL-6 concentration after } \\
\text { exposure to IL-1 } \beta / T N F \alpha^{+} \text {(IQR) }\end{array}$ & $\begin{array}{l}21914 \\
(6998 \\
50034) \\
n=134\end{array}$ & - & $\begin{array}{l}21914 \\
(6357 \\
48714)\end{array}$ & $\begin{array}{l}22307 \\
(6368 \\
50227)\end{array}$ & $\begin{array}{c}26960 \\
(5571,53452)\end{array}$ \\
\hline $\begin{array}{l}\text { Median increase in GMCSF concentration } \\
\text { after exposure to IL-1 } \beta / T N F \alpha^{\dagger} \text { (IQR) }\end{array}$ & $\begin{array}{c}633(218 \\
478) \\
n=134\end{array}$ & - & $\begin{array}{c}629(276, \\
1446)\end{array}$ & $\begin{array}{c}632(279 \\
1450)\end{array}$ & $\begin{array}{c}701(254 \\
1478)\end{array}$ \\
\hline
\end{tabular}

John Wiley \& Sons, Inc. 
E-Table 2. Median (interquartile range) cytokine concentration in the supernatant from neonatal nasal airway epithelial cell culture after treatment with house dust mite in groups stratified by the presence of recent wheeze at four years of age. The units are $\mathrm{pg} / \mathrm{mg}$ protein. The difference in RANTES was significant $(p=0.042)$ but none of the other comparisons between groups were significant. ND=not detected.

\begin{tabular}{|c|c|c|}
\hline Mediator & $\begin{array}{l}\text { Wheeze at four years } \\
\qquad n=10\end{array}$ & $\begin{array}{c}\text { No wheeze } \\
n=62\end{array}$ \\
\hline VEGF & $1696[667.2,3113]$ & $2427[1324,3731]$ \\
\hline RANTES/CCL5 & $3.0[1.1,41.8]^{*}$ & $14.3[3.4,115.2]$ \\
\hline MCP-1/CCL2 & 568 [ND, 91.9] & $40.1[6.8,169.6]$ \\
\hline IL-3 & $1.6[N D, 7.6]$ & $3.7[1.1,7.2]$ \\
\hline IL-10 & $0.2[\mathrm{ND}, 1.1]$ & $\mathrm{ND}[\mathrm{ND}, 8.2]$ \\
\hline IL-17A & $0.3[\mathrm{ND}, 1.7]$ & ND [ND, 0.1] \\
\hline IFN-y & ND $[N D, 0.6]$ & ND $[N D, 8.2]$ \\
\hline eotaxin & ND [ND, ND] & ND [ND, ND] \\
\hline MIP1- $\alpha / C C L 3$ & $5.2[N D, 22.1]$ & ND [ND, 2.3] \\
\hline MIP1- $\beta / C C L 4$ & $0.1[\mathrm{ND}, 2.6]$ & $0.8[N D, 9.2]$ \\
\hline TNF & $56.4[1.9,100.0]$ & $35.4[3.9,166.6]$ \\
\hline
\end{tabular}

John Wiley \& Sons, Inc. 
E-Table 3. Median (interquartile range) cytokine concentration in the supernatant from neonatal nasal airway epithelial cell culture after treatment with IL-1 $\beta$ and TNF $\alpha$ in groups stratified by the presence of recent wheeze at four years of age. The units are $\mathrm{pg} / \mathrm{mg}$ protein. There were no significant differences in cytokine concentration between the two groups. ND=not detected

\begin{tabular}{|c|c|c|}
\hline Mediator & $\begin{array}{l}\text { Wheeze at four years } \\
\qquad n=10\end{array}$ & $\begin{array}{c}\text { No wheeze } \\
n=78\end{array}$ \\
\hline VEGF & $2631[1912,4983]$ & $4646[254,6392]$ \\
\hline RANTES/CCL5 & $142[15,287]$ & $131[26,377]$ \\
\hline MCP-1/CCL2 & $283(50,1890)$ & $1021[272,2624]$ \\
\hline IL-3 & ND [ND, 1.1] & ND [ND, 1.4] \\
\hline IL-10 & ND $[N D, 1.8]$ & ND [ND, 1.6] \\
\hline IL-17A & ND [ND, 2.6] & ND [ND, 3.5] \\
\hline IFN-y & ND [ND, 3.6] & ND [ND, 2.8] \\
\hline eotaxin & ND [ND, 4.2] & ND [ND, 2.3] \\
\hline MIP1- $\alpha / C C L 3$ & ND [ND, 14.3] & ND [ND, 21.2] \\
\hline MIP1- $\beta / C C L 4$ & $48.6[10.8,213.8]$ & $56[18,173]$ \\
\hline
\end{tabular}

John Wiley \& Sons, Inc. 
E-Table 4. Median (interquartile range) cytokine concentration in the supernatant from neonatal nasal airway epithelial cell culture after treatment with lipopolysaccharide in groups stratified by the presence of recent wheeze at four years of age. The units are $\mathrm{pg} / \mathrm{mg}$ protein. There were no significant differences in cytokine concentration between the two groups. ND=not detected.

\begin{tabular}{|c|c|c|}
\hline Mediator & $\begin{array}{l}\text { Wheeze at four years } \\
\qquad n=5\end{array}$ & $\begin{array}{c}\text { No wheeze } \\
n=33\end{array}$ \\
\hline VEGF & $2836[1712,3564]$ & $2862[1817,1396]$ \\
\hline RANTES/CCL5 & $3.1[1.5,5.9]$ & $3.4[1.2,7.4]$ \\
\hline MCP-1/CCL2 & $14.5[3.8,155.1]$ & $36.1[9.6,188]$ \\
\hline IL-3 & $2.9[1.0,4.7]$ & $2.0[\mathrm{ND}, 11.2]$ \\
\hline IL-10 & $1.1[0.4,2.8]$ & $1.5[\mathrm{ND}, 5.1]$ \\
\hline IL-17A & $1.7[N D, 10.7]$ & ND $[N D, 5.7]$ \\
\hline IFN-y & ND $[N D, 6.0]$ & $1.9[N D, 5.2]$ \\
\hline eotaxin & $N D[N D, 0.2]$ & ND [ND, 3.6] \\
\hline MIP1- $\alpha / C C L 3$ & ND [ND, 9.2] & ND [ND, 10.5] \\
\hline MIP1- $\beta / C C L 4$ & ND $[N D, 3.6]$ & $\mathrm{ND}[\mathrm{ND}, 0.6]$ \\
\hline TNF & $4.5[0.9,8.8]$ & $11.4[5.1,18.8]$ \\
\hline
\end{tabular}

John Wiley \& Sons, Inc. 


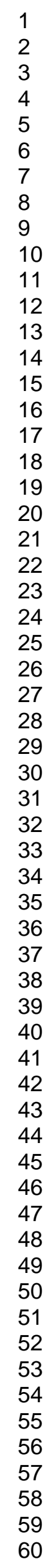


1

2

3

4

5

6

7

8

9

10

11

12

13

14

15

16

17

18

19

20

21

22

23

24

25

26

27

28

29

30

31

32

33

34

35

36

37

38

39

40

41

42

43

44

45

46

47

48

49

50

51

52

53

54

55

56

57

58

59

60

E-Table 5. Median (interquartile range) absolute cytokine concentration in the supernatant from neonatal nasal airway epithelial cell culture where cells were only exposed to medium alone in groups stratified by the presence of recent wheeze at four years of age. The units are $\mathrm{pg} / \mathrm{mg}$ protein. There were no significant differences in cytokine concentration between the two groups. $\mathrm{ND}=$ not detected

\begin{tabular}{|c|c|c|}
\hline Mediator & Wheeze at four years & No wheeze \\
& & $n=78$ \\
\hline VEGF & $1295[857,2972]$ & $2335[1186,4052]$ \\
\hline RANTES/CCL5 & $2.7[N D, 13.4]$ & $3.4[N D, 7.0]$ \\
\hline MCP-1/CCL2 & $0.5[N D, 8.7]$ & $5.0[N D, 75.2]$ \\
\hline IL-3 & ND [ND, 1.1] & ND [ND, 1.8] \\
\hline IL-10 & ND [ND, 0.9] & ND [ND, 0.5] \\
\hline IL-17A & ND [ND, ND] & ND ND, 0.1] \\
\hline IFN- $\gamma$ & ND [ND, 0.5] & ND $[N D, 0.9]$ \\
\hline eotaxin & ND [ND, ND] $]$ \\
\hline MIP1- $\alpha / C C L 3$ & ND [ND, 4.0] & ND [ND, 4.2] \\
\hline MIP1- $\beta / C C L 4$ & ND [ND, 0.1] & ND [ND, ND] \\
\hline TNF & $0.2[N D, 8.7]$ & ND [ND, 1.4] \\
\hline & & \\
\hline
\end{tabular}

John Wiley \& Sons, Inc. 
E-Table 6. Median (interquartile range) cytokine concentration in the supernatant from neonatal nasal airway epithelial cell culture in groups stratified by wheeze outcome by four years of age. The units are $\mathrm{pg} / \mathrm{mg}$ protein. ${ }^{*} \mathrm{p}<0.001, \dagger \mathrm{p}=0.035, \neq \mathrm{p}=0.004, \uparrow \mathrm{p}=0.031$ and $¥ \mathrm{p}=0.025$ for comparison with no wheeze reported. NR=no results available

\begin{tabular}{|c|c|c|c|c|}
\hline & Mediator & Recent wheeze at four years & Wheeze resolved by four years & No wheeze reported \\
\hline \multirow{3}{*}{$\begin{array}{l}\text { Absolute increase in } \\
\text { concentration after } \\
\text { treatment with IL-1 } \beta \text { and }\end{array}$} & IL-8/CXCL8* & $55785(33470,69303)(n=10)^{*}$ & $73950(53010,108010) n=5$ & $116550(86895,183980)(n=73)$ \\
\hline & IL-6 & $6361(1559,24745)(n=10) \dagger$ & $32655(14105,35102)(n=5)$ & $29373(12299,56938)(n=73)$ \\
\hline & GMCSF & $76(22,613)(n=10) \ddagger$ & $299(87,580)(n=5)$ & $1050(432,1686)(n=73)$ \\
\hline TNF $\alpha$ & ICAM & $541(222,1200)(n=10)$ & $986(520,2808)(n=5)$ & $1322(684,2146)(n=73)$ \\
\hline \multirow{2}{*}{$\begin{array}{l}\text { Absolute increase in } \\
\text { concentration after }\end{array}$} & IL-8/CXCL8 & $2200(0,7970)(n=5)$ ๆ & NR & $17810(10260,38130)(n=33)$ \\
\hline & IL-6 & $2252(0,21447)(n=5)$ & $N R$ & $9983(741,40795)(n=33)$ \\
\hline \multirow{2}{*}{$\begin{array}{l}\text { treatment with } \\
\text { lipopolysaccharide }\end{array}$} & GMCSF & $16(0,428)$ & NR & $110(13,637)(n=33)$ \\
\hline & ICAM & $15(0,425)$ & NR & $186(33,597)(n=33)$ \\
\hline Absolute increase in & IL-8/CXCL8 & $2450(1350,60630)(n=10)$ & $30900(17295,34665)(n=5)$ & $18120(6150,36880)(n=57)$ \\
\hline
\end{tabular}




\begin{tabular}{|c|c|c|c|c|}
\hline \multirow{3}{*}{$\begin{array}{c}\text { concentration after } \\
\text { treatment with house }\end{array}$} & IL-6 & $343(0,7897)(n=10)$ & $19898(8921,27034)(n=5)$ & $15093(1245,25941)(n=57)$ \\
\cline { 2 - 5 } dust mite & GMCSF & $0(0,66)(n=10)$ & $196(18,546)(n=5)$ & $126(18,353)(n=57)$ \\
\cline { 2 - 5 } & ICAM & $22(0,117)(n=10) ¥$ & $578(197,973)(n=5)$ & $293(60,717)(n=57)$ \\
\hline \multirow{3}{*}{\begin{tabular}{l} 
Untreated culture \\
\cline { 2 - 5 }
\end{tabular}} & IL-8/CXCL8 & $3530(1850,6310)(n=11)$ & $7570(2250,12930)(n=5)$ & $6740(3940,14410)(n=75)$ \\
\cline { 2 - 5 } & IL-6 & $1470(132,8244)(n=11)$ & $8803(1246,20594)(n=5)$ & $3782(897,10440)(n=75)$ \\
\cline { 2 - 5 } & GMCSF & $12(2,212)(n=11)$ & $16(2,279)(n=5)$ & $43(11,242)(n=75)$ \\
\hline
\end{tabular}

